\title{
PERSEPSI JAMA'AH TAREKAT TERHADAP SYARI'AT (STUDI KASUS JAMA'AH TAREKAT HAQ NAQSYABANDIYAH DI KOTA PONTIANAK)
}

\author{
Moh. Gitosaroso
}

\begin{abstract}
Abstrak
Anggapan miring terhadap kelompok-kelompok Tarekat, seringkali disebabkan oleh tampilan mereka yang seolah-olah melupakan syari'at. Selain itu, banyaknya ritual keagamaan yang oleh sementara pihak, dikatakan ghuluw (berlebih-lebihan), hal ini menambah panjang daftar penyebab ketakutan masyarakat untuk bergabung dalam tarekat. Persoalan ini sesungguhnya terletak pada persepsi masyarakat terhadap syari'at, dan bagaimana jama'ah tarekat dalam memposisikan syari'at. Boleh jadi persepsi mereka berbeda, sehingga tampilan yang muncul menjadi berbeda pula. Penelitian ini berusaha mengungkap persepsi jama'ah tarekat terhadap keberadaan syari'at dalam upaya mencapai kedekatan diri sedekat-dekatnya dengan Tuhan. Sebagai sampelnya diambil jama'ah Tarekat Haq Naqsyabandiyah di Kalimantan Barat. Tentu saja berbeda antara jama'ah tarekat yang satu dengan yang lainnya, sehingga hasil penelitian ini hanya bersifat parsial. Penelitian ini merupakan penelitian kualitatif yang didukung oleh data kuantitatif. Data diperoleh melalui observasi partisipatif, wawancara dan kuesioner.

Pengumpulan data dilakukan dengan teknik random sampling, yaitu sebanyak 21 responden dengan 21 pertanyaan terstruktur yang fleksibel berdasarkan keadaan sebenarnya dari responden. Metode Analisis yang digunakan adalah metode deduktifinduktif, artinya dari kondisi yang umum ke kondisi yang khusus. Berdasarkan hasil penelitian, diperoleh kesimpulan sederhana, bahwa pada dasarnya semua jama'ah tarekat, sangat mengedepankan syari'at. Namun, dalam kasus jama'ah Tarekat Haq Naqsyabandiyah di Kalimantan Barat, penyimpangan terjadi akibat kurangnya pembinaan jama'ah terkait dengan persoalan-persoalan syari'at.
\end{abstract}

Kata Kunci: Persepsi, Syari'at, Tarekat, THN.

\section{A. Pendahuluan}

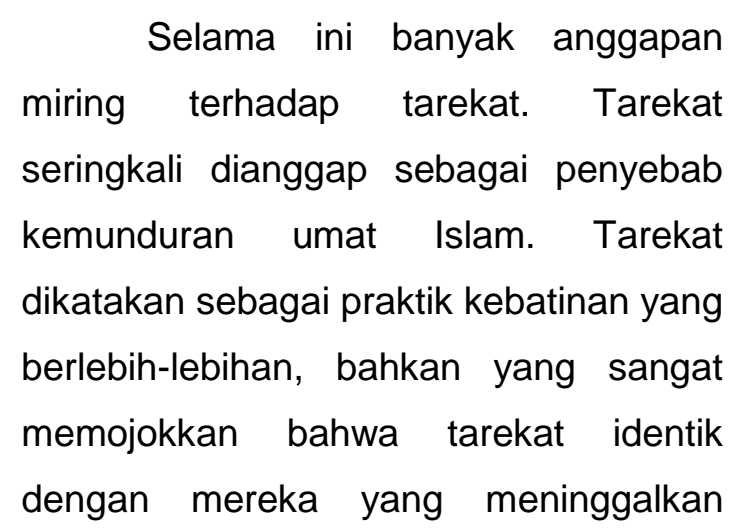

syari'at. Karena anggapan tersebut, banyak orang yang enggan bergabung dalam tarekat. Padahal sesungguhnya, tarekat adalah cara yang dapat dipilih untuk menjalankan syari'at yang bermakna. Tarekat mengisi kekosongan jiwa (sebagai ruh), di kala seseorang menjalankan kewajiban syari'at. Sebab, ibadah tanpa ruh, hanyalah sebatas 
mengerjakan pekerjaan ragawi yang tak membekas dalam kehidupan sehari-hari. la tak ubahnya seperti fitness, atau olah raga lainnya, yang hanya akan berpengaruh pada kesehatan jasmani. Sementara ibadah yang dimaksudkan dalam syari'at, tentu saja secara vertikal bersifat transendental kepada Allah SWT, di mana hasil yang diharapkan, bukan hanya ragawi, tapi juga ruhani.

Oleh karena itu, pemahaman terhadap syari'at secara utuh, adalah sesuatu yang mutlak wajib dimiliki oleh orang-orang yang ingin menjalan tarekat, demikian pula dengan mereka yang murni ingin menjalankan syari'at. Pemahaman tersebut akan menentukan bagaimana seseorang akan menjalankan keislaman secara utuh di muka bumi, dalam rangka mencapai kedekatan diri sedekatdekatnya dengan Tuhan. Sementara bagi mereka yang hendak menjalankan tarekat, maka pemahaman terhadap tarekat, selain juga syari'at, mutlak harus komprehensip. Kesalahan persepsi atas keduanya -syari'at dan tarekat- akan menjerumuskan seseorang dalam menjalankan keislamannya.

Penelitian ini dilakukan dengan tujuan untuk melihat persepsi jama'ah tarekat terhadap syari'at. Melalui penelitian ini, diharapkan dapat ditemukan penyebab utama dari

Redaksi Pontianak Post, "Satukan Hati, Raih Kebahagiaan Dunia dan Akhirat", Pontianak Post 28 Desember 2009. munculnya anggapan miring sementara pihak terhadap tarekat, sehingga mereka enggan untuk bergabung, bahkan menghindar dari tarekat. Sampel persepsi diperoleh dari jama'ah Tarekat Haq Naqsyabandiyah di Kalimantan Barat. Studi kasus secara parsial terhadap jama'ah tarekat di Indonesia, yang masuk dalam jajaran tarekat Mu'tabarah (diakui).

Tarekat Haq Nasyabandiyah (selanjutnya disingkat THN), merupakan tarekat yang dinisbatkan kepada Syeikh Bahauddin An-Naqsyabandi, yang didirikan oleh Syeikh Abdussamad Habibullah pada tahun 1986 di Mataram, Nusa Tenggara Barat. Tarekat ini telah berkembang di berbagai wilayah di Nusantara, termasuk di wilayah Kalimantan Barat. Keberadaannya di Kalimantan Barat, dipimpin oleh Syeikh K.H. Agus Sukarmin Al-Fattah Habibullah, $\mathrm{MBA}^{1}$, berpusat di JI. Sungai Landak Timur No. 56 Perumnas IV Pontianak Timur, sejak tahun $2001^{2}$.

Saat ini, tarekat Haq Naqsyabandiyah di wilayah Kalimantan Barat telah berkembang pesat, dengan jumlah jama'ah \pm 4.000 (empat ribu) orang, tersebar di berbagai Kabupaten dan Kota. Jama'ahnya terdiri dari berbagai kalangan, mulai dari masyarakat petani, nelayan, buruh, PNS, Polri, hingga wiraswasta menengah ke bawah.

2 Muh. Gitosaroso, Tarekat Haq Naqsyabandiyah di Kalimantan Barat: Studi Kasus di Kecamatan Pontianak Timur (Jurnal Dakwah Al-Hikmah, Vol.7. No.1, Tahun 2013). HIm. 68-72. 
Termasuk juga kalangan Mu'allaf, pesantren dan non pesantren.

Berdasarkan pengamatan dan wawancara sekilas dengan berbagai kalangan jama'ah, terdapat persoalan mendasar yang cukup mengkhawatirkan, antara lain: 1) Mereka ini cenderung eksklusif dalam beragama dan bermasyarakat; 2) Kebanyakan mereka hanya ikut-ikutan, tidak memahami secara mendalam mengenai posisi tarekat dalam Islam; 3) Ada juga yang meninggalkan syari'at (tidak shalat, puasa dan lain sebagainya), karena yakin telah memperoleh ilmu Syahadah. Meski demikian, sebagian besar tetap tekun menjalankan syari'at.

Tulisan ini mencoba melaporkan hasil penelitian mengenai persepsi jama'ah THN dalam persoalan syari'at. Jama'ah THN yang dimaksud, di batasi pada jama'ah yang berada di Kalimantan Barat. Tentu saja, akan banyak sekali perbedaan antara jama'ah THN di wilayah ini dengan di wilayah lainnya di seluruh Indonesia dan dunia.

\section{B. Syari'at dan Tarekat}

Islam dibangun atas konstruksi tiga pilar, yaitu: Iman, Islam dan Ihsan. Ketiga pilar itu menyangga bangunan Islam yang agung. Melalui pilar Iman, cabang-cabang keilmuan pendukung dalam mewujudkan makna iman, terus berkembang. Kajian-kajian keimanan membangun struktur keilmuan yang dikenal dengan Tauhid, Ushuluddin, Teologi Islam dan Kalam. Masing-masing memiliki bangunan implementasinya, yakni bangaimana mengimplementasikan iman dalam kehidupan sehari-hari.

Kemudian, melalui pilar Islam, berkembang pula keilmuan yang membahas masalah yang berkaitan, seperti Fiqh dan Ushul Fiqh. Bahasan fiqh terus dikembangkan dalam berbagai aspek kehidupan, mulai dari Ibadah hingga Mu'amalah. Persoalan ibadah terkait dengan hukum ubudiyah sebagaimana yang diperintahkan oleh Allah SWT, sedangkan persoalan mu'amalah, terkait dengan hubungan antara manusia dengan manusia. Semua yang bersifat kehidupan duniawi, diatur dalam fiqh mu'amalah, seperti: politik, ekonomi, sosial, budaya dan lain sebagainya.

Selanjutnya, pada pilar Ihsan, berkembang sistem keilmuan yang disebut dengan ilmu Akhlak dan Tasawuf. Bentuk-bentuk aplikasi yang nyata dalam bidang keilmuan ini bisa bermacammacam, sesuai dengan hasil pemahaman masing-masing tokoh dan pengikutnya. Itulah sebabnya, muncul kelompokkelompok yang memiliki metode dan ciri khas tersendiri dalam upaya mengimplementasikan Iman, Islam dan Ihsan, yang dikenal dengan istilah tarekat. 
Syari'at berasal dari bahasa Arab yang berarti jalan yang lurus ${ }^{3}$. Jalan inilah yang harus dilalui oleh seorang Mu'min agar tidak tersesat. Jalan tersebut adalah jalan yang tidak luput dari pengawasan Allah SWT untuk setiap hamba-Nya. Menurut Samih Athif Az-Zain, syari'at tidak melupakan satu pun perbuatan seorang Mu'min, melalui Nash (teks) AlQur'an dan Al-Hadits, meletakkan "tandatanda" yang memperingatkan mukallaf akan maksud dan dorongan pensyari'atannya, agar ia mencocokkan diri pada setiap tanda yang $\operatorname{ada}^{4}$. Secara istilah, syari'at merupakan hukum yang ditetapkan oleh Allah SWT melalui RasulNya untuk hamba-hamba-Nya, agar mereka menta'ati hukum itu atas dasar iman, baik yang berkaitan dengan aqidah, amaliyah (ibadah dan mu'amalah), maupun dengan akhlaq ${ }^{5}$.

Dengan demikian, maka kedudukan syari'at terletak pada inti ajaran Islam secara keseluruhan. la merupakan tubuh dan segala tampilan yang muncul dalam seluruh bangunan Islam. la tersusun atas semua segi keislaman yang tampak dari luar maupun dalam agama ini. Semua itu memiliki tata aturan tersendiri yang diatur sedemikian rupa melalui al-Qur'an dan al-Sunnah.

Masjfuk Zuhdi, Pengantar Hukum Syariah (Jakarta: Haji Masagung, 1990), hlm. 1.

4 Samih Athif Az-Zain, Syari'at Islam: Dalam Perbindangan Ekonomi, Politik, dan Sosial sebagai Studi Perbandingan, Terjemahan Drs. Muzakir As dari judul Asli: Al-Islam Khuthuthun 'Aridhah: al-lqtishad-al-Hukm al-Ijtima' (Beirut:
Menjalankan syari'at, berarti menjalankan Islam secara kaffah.

Sebagaimana syariat, tarekat (thariqah) juga berarti jalan, hanya saja syari'at diibaratkan dengan jalan raya (road), sementara tarekat adalah jalan kecil (path).Tarekat merupakan jalan spiritual yang ditempuh seorang sufi. Tarekat disebut juga "suluk", yang artinya perjalanan spiritual. Orangnya disebut "salik". Kata tarekat dapat juga digunakan untuk merujuk kepada sebuah kelompok persaudaraan atau ordo spiritual yang biasanya didirikan oleh para pengikut seorang sufi besar seperti, Abd al-Qadir Jilani, Sadzili, Jalal al-Din Rumi, dan lainlain. Nama terekat tersebut biasanya dinisbahkan kepada nama-nama pendirinya atau julukan yang di berikan oleh para pengikutnya ${ }^{6}$.

Tarekat memiliki ciri yang khusus, yakni dalam suatu tarekat terdapat Syeikh, upacara ritual, dan bentuk dzikir sendiri. Maknanya yang asli merupakan paduan yang khas dari doktrin, metode, dan ritual $^{7}$. Dalam tarekat ada istilah syeikh atau mursyid, maksudnya adalah guru tarekat; khalifah, maksudnya adalah wakil syekh atau mursyid; murid, maksudnya adalah pengikut ajaran suatu tarekat; baiat, yaitu perjanjian atau

Darul Kitabil Lubnaniy, Cet. IV, 1981), (Bandung: Husaini, 1988), hlm. 17-18.

5 Masjfuk Zuhdi, Pengantar Hukum ..., hlm. 1.

6 Ahmad Mustofa, Akhlak Tasawuf, (Bandung: Pustaka Setia, 1997), hlm. 280.

7 M. Solihin dan Rosihon Anwar, IImu Tasawuf (Bandung: Pustaka Setia, 2011), hlm. 204. 
sumpah setia murid kepada gurunya; wasilah atau rabitah, yaitu perantara guru (syekh) dengan muridnya; suluk, yaitu mengamalkan ajaran-ajaran yang telah diterima dari guru; dan ijazah, yaitu sebuah pengakuan guru kepada muridnya. $^{8}$

Selain itu ada pula amalanamalan khusus menurut aliran tarekat yang dianut, kemudian diamalkan oleh para muridnya secara bersama-sama dengan mursyid-nya, di suatu tempat yang disebut ribath, zawiyah, atau taqiyah. Wakil dari syekh atau mursyid ini disebut khalifah. Ada pengambilan sumpah dari murid di hadapan syekh. Lalu setelah sempurna menjalani tarekat, akan mendapatkan ijazah. Setelah mendapatkan ijazah, maka sang murid dapat menjadi khalifah syeikh atau boleh mendirikan tarekat lain jika diberi izin oleh syeikh. Mereka lebih terkonsentrasi pada amalan dzikir dan wirid malam dan siang hari dan dalam suasana kesepian? .

Dengan demikian, kedudukan tarekat dalam Islam terletak pada implementasi ajaran al-Ihsan. Menjalankan tarekat, berarti mengimplentasikan apa yang diajarkan dalam al-Ihsan. Implementasi itu dalam wujud, beribadah seolah-olah melihat Allah dan berusaha beribadah dengan

8 Mustofa, Akhlak Tasawuf, (Bandung: Pustaka Setia, 2014), hlm. 289. keyakinan bahwa Allah melihat apa yang dilakukan oleh hamba-Nya.

Persoalan syari'at, biasanya dibahas dalam ilmu fiqh. Ilmu memerinci berbagai hal yang terkait dengan ibadah dan mu'amalah. Persoalan-persoalan yang paling penting untuk dibahas dalam fiqih antara bersuci, shalat, zakat, puasa, haji, menikah, waris, dan lain sebagainya, yang membentuk sebuah bangunan peribadatan, yang sering kali disingkat dengan rukun Islam. Syahadat, shalat, puasa, zakat dan haji adalah pilar utama syari'at, di mana yang lainnya sebagai pendukung.

Berikut ini sekilas mengenai rukun Islam yang dimaksud:

Pertama, Syahadat adalah lafal yang sangat sederhana, yang berisi sebuah pengakuan bahwa tidak ada Tuhan selain Allah dan Muhammad SAW adalah utusan Allah. Dalam pengertian yang lebih mendalam, syahadat berarti tekad kuat, ingin menjalani hidup sesuai dengan kehendak dan aturan Allah dan rasul-Nya.

Kedua, Shalat. Sebagian besar umat Islam tahu bahwa shalat adalah salah satu bentuk dzikrullah. Shalat dalam pengertian inilah (wajib, sunnah, wustha) yang akan mampu membawa orang yang shalat sanggup menjauhi fahsya' dan munkar. Shalat melatih

9 Bachrun Rif'i dan Hasan Mud'is, Filsafat Tasawuf, (Bandung: Pustaka Setia, 2010), hlm. 235. 
meninggalkan dunia materi, lafal takbir mengingatkan betapa kecilnya dunia materi itu. Khusyu' dalam shalat melatih melupakan dunia materi ${ }^{10}$. Shalat memang merupakan rukun Islam yang kedua, namun pada dasarnya shalat adalah bagian utuh dari kelima rukun Islam yang ada. Bacaan-bacaan yang ada di dalamnya telah mencakup makna yang tersirat dalam kelima rukun lainnya. Dalam shalat, syahadat dibaca pada saat tasyahud, puasa dilakukan pada saat sepanjang shalat, haji adalah makna puncak pelaksanaan ibadah shalat.

Ketiga, Zakat adalah rukun wajib, sunnahnya adalah shadaqah, hibah, infaq, waqaf dan lain-lain. Orang yang sedang naik menuju Allah, sebaiknya tidak terlalu membedakan antara yang wajib dan yang sunnah ${ }^{11}$. Allah SWT menegaskan dalam al-Qur'an surat AlTaubah [9]: 103, bahwa zakat berfungsi sebagai alat pembersih dan pensuci atas setiap mu'min. "Ambillah zakat dari sebagian harta mereka, dengan zakat kamu membersihkan dan mensucikan mereka. Sesungguhnya doa kamu menjadi ketenteraman jiwa mereka. Dan Allah Mendengar lagi Maha Mengetahui". Itu artinya, kebersihan jasmani dan kesucian ruhani akan dapat diperoleh melalui zakat.

10 Ahmad Tafsir, "Rukun Islam Sebagai Maqamat Menuju Tuhan", dalam: http://www.rasailmedia.com/index.php/en/13artikel/22-rukun-islam-sebagai-maqamatmenuju-tuhan, diakses pada tanggal 23 September 2016.
Menurut M. Quraish Shihab dalam tafsir al-Mishbah-nya, ayat ini merupakan perintah kepada Rasululllah SAW, berkaitan dengan Abu Lubabah dan rekan-rekannya, yang enggan untuk ikut pergi ke medan perang, dikarenakan harta yang dimilikinya. Akan tetapi ayat ini bersifat umum (berlaku pada semua umat Islam), tentang pentingnya membayar zakat bagi umat dan wajibnya penguasa memungut zakat. Selain itu, ada yang lebih penting, yaitu salah satu cara untuk mensucikan jiwa dan membersihkan harta, yang berhubungan dengan taubatnya seseorang ${ }^{12}$.

Keempat, Puasa adalah ibadah yang menjadi simbol kepasrahan total kepada Allah SWT. Bagaimana tidak? Seseorang tidak ada akan mampu menyelesaikan puasanya, tanpa benarbenar yakin bahwa Allah ada di dalam hatinya dan di mana-mana. Karenanya, puasa merupakan urusan ibadah antara orang yang berpuasa dengan Tuhannya. Tak ayal, maqam ini adalah maqam tertinggi di antara maqam lainnya.

Kelima, Secara umum panggilan Allah ialah agar melaksanakan hajji itu, akan tetapi secara khusus panggilan Allah ialah agar kita datang kepada-Nya. Maksudnya ialah agar si pelaksana haji bertemu dengan-Nya. Ketika wukuf di

11 Ahmad Tafsir, "Rukun Islam Sebagai Maqamat ..., Ibid.

12 M. Quraish Shihab, Tafsir al-Mishbah: Pesan dan Kesan Keserasian al-Qur'an (Jakarta: Lentera Hati, 2002), hlm. 705-710. 
'Arafah, pada dasarnya telah sampai kepada kata ma'rifat. Sebab, kata ini berakar dari kata arafa artinya kenal. Seharusnya, ketika wukuf, seorang muslim/muslimat bisa merasakan mengenal (arif) Allah SWT. ${ }^{13}$

Istilah syari'at dalam dunia hakikat (tasawuf) memiliki makna tersendiri, yang dapat dikatakan berbeda dari pengertian yang diberikan oleh para ahli hukum Islam. Para ahli hukum Islam, memaknai syari'at sebagai seluruh ketentuan yang ada di dalam Al-Qur'an dan As-Sunnah, baik yang berhubungan dengan akidah, akhlak maupun aktivitas manusia, baik yang berupa ibadah maupun muamalah.

Sementara bagi kaum sufi, syari'at berarti amal ibadah lahiriah; sedangkan hakikat dalam pandangan tasawuf adalah inti atau rahasia yang paling dalam dari syari'at: rasa, keadaan, dan akhir dari perjalanan yang ditempuh oleh seorang sufi. Jika gerak-gerik dan bacaan-bacaan shalat adalah syari'at, maka dialog spiritual bertemu antara seorang abid (hamba) dengan ma'bud (yang disembah) adalah hakikatnya. Jika gerak-gerik dan bacaan-bacaan yang ada dalam ibadah haji adalah syari'at maka berjumpa dengan Allah adalah hakikatnya. Dalam pandangan sufi, antara syari'at dan hakikat adalah dua hal yang tidak dapat

13 Ahmad Tafsir, "Rukun Islam Sebagai Maqamat ..., Op.Cit.

14 Ahmad Bangun Nasution Dan Rayani Hanum Siregar, Akhlak Tasawuf, Raja Grafindo Persada, Jakarta, 2015, hlm. 77-79. dipisahkan; dan ma'rifat adalah ujung perjalanan dari ilmu pengetahuan tentang syari'at dengan kesediaannya menempuh jalan (tarekat) dalam mencapai hakikat, itulah yang disebut dengan ma'rifat ${ }^{14}$.

Syari'at, dalam tarekat merupakan fondasi yang menopang hakikat. Tarekat yang baik adalah tarekat yang tidak meninggalkan syari'at, karena syari'at merupakan tempat berpijaknya hakikat. Itulah sebabnya, ketika terjadi banyak penyimpangan tarekat, Ibnu Taimiyah tampil sebagai pembela syari'at. Namun, bukan berarti Taimiyah membenci tarekat, ia hanya meluruskannya kembali ke syari'at. Tarekat yang syari'at inilah yang disebut dengan tasawuf masyru'.

Tasawuf masyru' merupakan tasawuf yang disyari'atkan. Tokoh yang menganut paham ini adalah Ibnu Taimiyah. Masyru' ini artinya disyari'atkan. Kata masyru' juga digunakan dalam kata-kata dzikir. Artinya dzikir yang disyari'atkan. Tasawuf masyru' adalah amalan dalam tasawuf yang disyari'atkan seperti berkhalwat, beruzlah, dan pengasingan diri, karena menurut Ibnu Taimiyah, ini merupakan sebagian dari perintah Allah SWT ${ }^{15}$.

Menurut Ibnu Taimiyah, sesuatu yang tidak disyari'atkan itu disebut ghairu masyru', seperti mengeraskan suara.

15 Rushdi Ramli, Khazanah Cinta Ilahi, (Selangor: Karya Bestari, 2010), hlm. 207. 
Karenanya ini merupakan amalan bid'ah ditinjau dari caranya. Bid'ah, sebagaimana praktek sebagian ahli tasawuf yang meninggalkan makanan yang hukumnya halal dalam rangka mendekatkan diri kepada Allah dan menyiksa diri ${ }^{16}$.

Untuk menuju akhirat manusia harus melewati tiga tahapan, yakni melalui syari'at, tarikat, dan hakikat. Hakikat tanpa syari'at menjadi batal, dan syari'at tanpa hakikat menjadi kosong. Syari'at ibarat kapal, yakni sebagai instrumen mencapai tujuan. Tarikat ibarat lautan, yakni sebagai wadah yang mengantar ketempat tujuan, hakikat ibarat mutiara yang sangat berharga dan banyak manfaatnya. Syari'at adalah peraturan dan undang-undang yang bersumber kepada wahyu Allah. Tarikat adalah suatu jalan yang ditempuh dengan sangat waspada dan berhati-hati ketika beramal ibadah. Untuk menempuh jalan menuju akhirat, hakikat adalah fase terakhir. Dalam hakikat itulah manusia yang mencari dapat menemukan ma'rifatullah. la menemukan hakikat yang tajalli dari kebesaran Allah penguasa langit dan bumi ${ }^{17}$.

Dengan demikian, kedudukan syari'at dalam tarekat adalah sebagai fondasi yang menjadi penopang bagi seluruh bangunan tarekat. Ketika

16 Sa'id Hawwa dan Abu Ridho, Membina Angkatan Mujahid: Studi Analitis atas Konsep Dakwah Hasan Al-Banna dalam Risalah Ta'alim (Jakarta: Era Intermedia, 1999), hlm. 1. seseorang menjalankan tarekat, tapi tidak bersyari'at, maka apalah artinya tarekat itu, ia akan sia-sia, berdiri di atas fondasi yang rapuh, bahkan bisa terjerembab ke dalam jurang kehancuran dan murka Allah SWT. Namun, sebaliknya, jika seseorang menjalankan syari'at tanpa adanya tarekat, maka hakikat dari syari'at itu akan sulit dicapai, sehingga ibarat tubuh tanpa ruh.

\section{Persepsi Jama'ah THN terhadap Tarekat dan Syari'at}

Sebelum memahami tentang persepsi jama'ah THN terhadap syari'at dan tarekat itu sendiri, ada baiknya peneliti ketengahkan terlebih dahulu mengenai keberadaan tarekat tersebut. Penampilan data ini dimaksudkan sebagai gambaran sekilas mengenai THN yang ada di Kalimantan Barat. Dengan demikian, ada benang merah antara persepsi jama'ahnya dengan syari'at.

Perguruan Tarekat Haq Naqsyabandiyah memiliki ribuan orang jamaah, tersebar hampir di seluruh Indonesia, bahkan sebagian di antaranya ada di berbagai belahan dunia. Jamaah Tarekat Haq Naqsyabandiyah tersebar di desa, kelurahan, kecamatan, kabupaten di seluruh Provinsi Nusa Tenggara Barat, Nusa Tenggara Timur, Bali, Jawa Timur, Jawa Tengah, Kalimantan Barat,

\footnotetext{
17 Toriquddin, Sekularitas Tasawuf, UIN-Malang Press, Malang, 2008, hlm. 99-107.
} 
Kalimantan Timur, Kalimantan Selatan, Batam, Riau, Sulawesi Tengah, Papua dan lain sebagainya. Sementara jamaah luar negeri tercatat antara lain, dari Belanda 3 orang, Tunisia 4 orang, Amerika Serikat 4 orang, dan Malaysia 10 orang $^{18}$.

Untuk melakukan pembinaan jamaah secara berkesinambungan, maka yayasan membentuk Pengurus Besar (PB) Perguruan Tarekat Haq Naqsyabandiyah untuk tingkat Pusat, dan Pengurus Wilayah (PW) untuk tingkat Provinsi. Pengurus Cabang (PC) untuk tingkat Kabupaten/Kota, Pengurus Anak Cabang (PAC) untuk tingkat Kecamatan dan Pengurus Ranting (PR) untuk tingkat Desa/Kelurahan. Di setiap ranting, terdapat kelompok-kelompok dzikir atau majelis taklim yang beranggotakan 20 sampai 50 orang jamaah.

Tarekat Haq Naqsyabandiyah ajarannya berasal dari aliran Tarekat Naqsyabandiyah yang didirikan oleh Maulana Syaikh

Bahauddin Naqsyabandiy dari Bukhara (1390 M) di Jazirah Afrika. Ajaran ini berkembang di pulau Lombok sejak tahun 1890/1891 dibawa dan dikembangkan oleh Maulana Syaikh Haji Muhammad Ali Batu dari Batubangka Desa Sakra Kecamatan Sakra, Lombok Timur.

Tarekat Haq Naqsyabandiyah berasal dari kata "tarekat" yang bermakna

18 Data Tabulasi Jama'ah, Laporan Pengurus Yayasan, tahun 2010. jalan, yaitu jalan, metode, atau cara yang dapat ditempuh orang-orang yang sedang berjalan meraih ridho Allah SWT. Hal ini sejalan dengan firman Allah Swt di dalam Surah Al-Jin ayat 11: "Dan sesungguhnya di antara kami ada orang-orang yang shaleh dan di antara kami ada (pula) yang tidak demikian halnya. Kami menempuh jalan (tarekat) yang berbeda-beda."

Kata berikutnya adalah "Haq" berasal dari kata "hakekat" yang bermakna benar atau kebenaran. Tetapi dalam kaitan dengan tarekat ini, yang dimaksud dengan kata "haq" adalah roh, jiwa, nyawa yang ada pada manusia. Jadi, tujuan perjalanan melalui tarekat pada umumnya dan tarekat Haq Naqsyabandiyah pada khususnya, adalah mengupayakan agar ruh yang diterima dari Allah SWT digunakan di jalan Allah SWT dan dijaga kesuciannya agar saat kembali kepada Allah SWT, ruh dalam keadaan suci seperti saat diterima dari-Nya.

Naqsyabandiyah, berasal dari nama pendiri tarekat ini, yaitu Bahauddin Naqsyabandi, bermakna lukisan. Karena pengajaran melalui tarekat ini, ditempuh melalui pelukisan atau penggambaran yang dimaksudkan untuk memudahkan pengertian, pemahaman, keyakinan dan pengamalan. Segala sesuatu yang diterangkan dalam ajaran ini, dilakukan dengan pelukisan atau penggambaran. 
Misalnya, dengan menggunakan tamsil dan ibarat dalam memahami ayat-ayat Allah SWT yang tersurat dan tersirat di dalam al-Qur"an maupun ayat-ayat kauniyah yang tersebar nyata di sekitar kita.

Tarekat Haq Naqsyabandiyah di Kalimantan Barat, berusat di Pontianak. Tarekat ini dikembangkan di Kota Pontianak oleh Syeikh Agus Sukarmin alFattah Habibullah, MBA putra pertama dari delapan bersaudara dari pasangan Ahmad Hamid (almarhum) dan Karsimah (almarhumah). Tepatnya di bulan Agustus 2001, ia memulai kegiatannya dalam menyebarkan (mensyiarkan) ajaran tarekat ini kepada keluarganya yaitu orang tuanya dan saudara-saudaranya. Dimulai dari rumah orang tuanya di Jalan Komyos Sudarso Gang Rambe Jalur D No. 87 Komplek Perumahan Pemda Kalimantan Barat, Kelurahan Sungai Jawi Luar, Kecamatan Pontianak Barat, Kota Pontianak. Rumah orang tuanya tersebut dijadikan sebagai tempat sekretariat dan sekaligus sebagai wadah pembinaan ummat Islam yang sudah bergabung dengan Tarekat Haq Naqsyabandiyah. Hari demi hari pengikut dari tarekat Haq Naqsyabandiyah ini semakin bertambah banyak dan menyebar di Kota Pontianak dan sekitarnya. Tarekat Haq Naqsyabandiyah ini bersekretariat di alamat tersebut di atas sampai dengan akhir tahun 2002.
Kemudian di tahun 2003-2005, sekretariat tarekat Haq Naqsyabandiyah berpindah di Jalan Paralel Tol Kelurahan Tanjung Hilir Kecamatan Pontianak Timur, dengan mengontrak rumah masyarakat setempat. Pengikut tarekat ini semakin bertambah dan semakin menyebar luas. Untuk itu pengurus tarekat Haq Naqsyabandiyah berinisistif untuk mencari tempat khusus pembinaan jamaah tarekat. Sehingga, lahirlah secretariat baru. Sekretariat baru tersebut beralamat di Jalan Sungai Landak Timur No. 56 Perumnas IV Kecamatan Pontianak Timur Kota Pontianak.

Sejak tahun 2005, tepatnya di bulan Desember 2005, sekretariat ditetapkan di lokasi tersebut sampai dengan sekarang. Selanjutnya pembangunan dan renovasi gedung sekretariat baru terus dilakukan demi kenyamanan dan kemudahan jamaah tarekat dalam mengikuti pembinaan dan halaqah dzikir tarekat. Gedung sekretariat perguruan tarekat Haq Naqsyabandiyah sekarang, sudah berdiri dengan megah, dua lantai dengan aula pertemuan yang bisa menampung jamaah kurang lebih 500 orang. Pembinaan dan halaqah dzikir tarekat dilaksanakan setiap hari Selasa, Kamis dan Sabtu pada pukul 19.00 WIB sampai selesai dan tawajjuh/ pembaharuan lathifah thabi'i dilaksanakan setiap hari Ahad.

Jumlah jamaah yang terdata sampai dengan saat ini, kurang lebih 
2.150 jamaah yang tersebar di berbagai kota dan kabupaten di wilayah Kalimantan Barat. Pengikut terbanyak terdapat di Kota Pontianak dan Kabupaten Kubu Raya. Untuk jamaah di kota Pontianak kurang lebih 500 orang ${ }^{19}$.

Adapun kepengurusan Tarekat

Haq Naqsyabandiyah Cabang Kota Pontianak telah terbentuk dengan susunan pengurus sebagai berikut: Ketua (Badarudin), Wakil Ketua ( Zaenudin), Sekretaris (Ismail, S.Pd), dan Bendahara (Mukhlis). Di samping kepengurusan cabang kota, juga telah terbentuk kepengurusan tingkat anak cabang/ kecamatan di wilayah kota Pontianak, terdiri dari pengurus anak cabang Pontianak Timur, pengurus anak cabang Pontianak Utara, pengurus anak cabang Pontianak Barat dan Kota, serta pengurus anak cabang Pontianak Selatan dan Tenggara. Kedua kepengurusan anak cabang yang disebutkan terakhir masih bergabung dua kecamatan menjadi satu yaitu Kecamatan Pontianak Barat dan Kecamatan Pontianak Kota masih jadi satu pengurus anak cabang. Demikian juga Kecamatan Pontianak Selatan dan Kecamatan Pontianak Tenggara masih bergabung dalam satu kepengurusan anak cabang, dikarenakan satu diantara dua kecamatan tersebut jumlah jamaah

19 Wawancara dengan Sekretaris Pengurus Wilayah Tarekat Haq Naqsyabandiyah Wilayah Kalimantan Barat, Jum'at, 30 September 2016). belum begitu signifikan untuk mendirikan kepengurusan anak cabang tersendiri.

Program kegiatan masing-masing anak cabang berdiri sendiri sesuai kesepakatan bersama dan disetujui oleh pengurus cabang kota, pengurus wilayah dan pembimbing/badal mursyid. Kegiatan-kegiatan dimaksud antara lain pembinaan rutin dan khalaqah zikir, sosial kemasyarakatan dan lain-lain. Dalam kegiatan khalaqah zikir dan pembinaan masing masing anak cabang biasa dihadiri oleh guru pembimbing, pengurus wilayah, pengurus cabang kota dan jamaah ranting lain yang ada kesempatan untuk menghadiri khalaqah zikir tersebut.

Dengan demikian, dapat dipahami bahwa tarekat ini sangat pesat perkembangannya, sehingga melalui data ini saja, dapat dikatakan bahwa persepsi jama'at terhadap tarekat, sangat positif. Demikian juga dengan persepsi jam'ah THN terhadap syari'at. Namun, untuk lebih jelasnya akan diuraikan mengenai data hasil penelitian yang diperoleh.

$$
\text { Untuk mengetahui persepsi }
$$
jama'ah THN terhadap Syari'at dan Tarekat, peneliti menggunakan teknik penyebaran angket yang diringi dengan konfirmasi berupa observasi partisipatif dan wawancara. Pertanyaan yang berbentuk kuesioner dalam penelitian ini 
dibagi menjadi 2 kategori, yaitu: 1) Tarekat Murni yang bersifat Ekstrim; dan, 2) Tarekat yang Masyru' (bersandar penuh kepada syari'at). Kedua kategori di atas, dimunculkan dalam pilihan jawaban yang disediakan, yakni: Point A dan Point B. Sementara Point C dan D, merupakan pilihan alternative kecenderungan jama'ah, yang akan dilihat lagi apakah mendekati ke Point A atau ke Point B. Jika yang dipilih $\mathrm{C}$, maka mendekati Point $\mathrm{A}$, dan jika yang dipilin D, maka mendekati Point B.

Melalui data yang peroleh dari responden, terdapat sebaran angka sebagai berikut: 1) Jawawan A diperoleh dari 20 pertanyaan; dan, 2) Jawaban B diperoleh dari 17 pertanyaan. Sedangkan Jawaban C diperoleh dari 13 pertanyaan dan Jawaban D diperoleh dari 4 pertanyaan. Berdasarkan perolehan jawaban di atas, maka jumlah jawaban $A$ adalah 33 point, dan jumlah jawaban B adalah 21 point. Dengan demikian, dapat disimpulkan sementara bahwa persepsi jama'ah THN, masih didominasi oleh syari'at, yakni, 33:21.

Namun, ketika dikonfirmasikan dengan data observasi dan wawancara di lapangan, terjadi pemaksaan persepsi yang seolah-olah didominasi oleh syari'at, yang pada kenyataannya, banyak data yang diperoleh melalui wawancara dan observasi berbanding terbalik (21:33). Banyak oknum jama'ah yang memang belum paham secara baik mengenai syari'at, akan tetapi telah bergabung dan menekuni hakikat melalui tarekat.

Keadaan ini ada hubungannya dengan kurangnya pembinaan jama'ah dalam hal syari'at. Hampir seluruh materi yang dibahas dalam pembinaan jama'ah terfokus pada masalah aqidah dan akhlak. Sementara untuk masalah syari'at, nyaris tidak dibahas, meskipun dalam slide materi tetap terdapat bahasan mengenai rukun Islam yang harus selalu menyertai jama'ah dalam setiap kegiatan peribadatan atau kehidupan sehari-hari.

Persepsi Jama'ah Tarekat Haq Naqsyabandiyah di Kalimantan Barat terhadap Posisi Tarekat dalam Islam, nampak pada beberapa hal, yaitu:

a) Penerimaan mereka yang sangat baik dalam hadirnya Tarekat Haq Naqsyabandiyah dan tarekat-tarekat lain di Kalimantan Barat;

b) Pengenalan jama'ah terhadap THN, ternyata hanya melalui teman sejawat/teman kerja, berdasarkan informasi dan penampilan akhlak yang baik dari anggota yang sudah bergabung, menarik minat masyarakat lain untuk menjadi pengikut setia. Artinya, pengenalan mereka sangat sederhana, namun mampu merubah persepsi dan mengarahkan pilihan untuk bergabung;

c) Alasan mereka bergabung, kebanyakan bermotif Ingin mendekatkan diri sedekat-dekatnya 
dengan Tuhan. Selain itu, jawaban didominasi oleh motif untuk mengetahui ajaran Islam secara lengkap, baik Syari'at, Hakikat, Tarekat, maupun Ma'rifat, demi untuk mencapai kebahagiaan di dunia dan akhirat;

d) Sebelumnya, mayoritas jama'ah belum pernah bergabung dengan tarekat manapun. Artinya, mereka pada umumnya masih sangat awam terhadap tarekat; dan,

e) Manfaat yang diperoleh oleh jama'ah, pada umumnya adalah ketenangan batin.

Sementara Persepsi Jama'ah Tarekat Haq Nasyabandiyah Kalimantan Barat terhadap Syari'at, dapat dilihat dari pandangan dan pelaksanaan mereka terhadap beberapa hal yang terkait dengan syari'at, yaitu:

a) Syari'at dalam Islam merupakan aturan hukum yang harus dipatuhi dan dijalani oleh setiap umat Islam yang beriman;

b) Ajaran syari'at dalam THN dijadikan sebagai fondasi hakikat;

c) Jama'ah THN memfungsikan syari'at sebagai sarana untuk mencapai hakikat;

d) Kedudukan syari'at lebih lanjut merupakan fondasi dan kerangka bangunan tarekat;

e) Mencari nafkah hukumnya wajib sebagai sarana mencari ridho Allah SWT; f) Jama'ah THN harus beribadah, namun tetap harus menjalani dan berusaha untuk kebahagiaan dunia;

g) Memperdalam ilmu agama adalah wajib;

h) Shalat da'im adalah shalat yang dilakukan secara terus-menerus tanpa kenal waktu dan tempat, dengan selalu mengingat Allah SWT;

i) Shalat, ketika dalam perjalanan bisa dilakukan sesuai situasi dan kondisi, jika memungkinkan, jika tidak maka cukup dengan hati;

j) Shalat merupakan dzikir yang paling utama, sehingga shalat tidak boleh ditinggalkan;

k) Puasa ramadhan, berfungsi untuk menguatkan latifatul qalbi (kelembutan hati);

I) Zakat, diberikan kepada delapan asnaf, tapi dikuatkan dengan kecondongan hati;

m) Haji merupakan safar menuju Allah SWT;

n) Lebih penting zikir dari pada silaturahim;

o) Menikah itu wajib, asalkan tidak mengurangi rasa cinta kepada Allah SWT;

p) Berqurban, bisa diganti dengan uang;

q) Qurban diserahkan kepada orangorang yang betul-betul membutuhkan;

r) Shalat berjama'ah di masjid/mushalla perlu dilakukan, tapi melihat situasi dan kondisi diri sendiri; 
s) Jama'ah THN harus membaur dengan masyarakat;

t) Bersyahadat artinya mengucapkan dua kalimah syahadat dengan hati;

u) Syari'at dan tarekat dilaksanakan secara bersama-sama.

Dengan demikian, maka pada dasarnya jama'ah THN, memang cenderung kepada hakikat murni yang cukup ekstrim. Hal ini nampak pada setiap point jawaban dan pandangan mereka yang selalu dikaitkan dengan hakikatnya, seperti bersyahadat dengan hati, berqurban yang terpenting adalah penyerahannya yang ikhlas, puasa untuk menguatkan latifah qalbi, shalat diperjalanan dapat dilakukan dengan berdzikir, haji sebagai safar menuju Allah, dan lain sebagainya. Namun, setelah ditelaah lebih jauh (melalui wawancara dan observasi serta partisipasi langsung), dapat disimpulkan bahwa kondisi ini disebabkan oleh kurangnya pembinaan jama'at terhadap hal-hal yang menyangkut syari'at.

\section{Kesimpulan}

Berdasarkan hasil telaah yang cukup panjang mengenai persepsi jama'ah Tarekat Haq Naqsyabandiyah, sebagaimana diuraikan pada pada babbab sebelumnya, dapat disimpulkan beberapa point berikut ini:

1. Berdasarkan data yang diperoleh, persepsi jama'ah terhadap tarekat, sangat positif, sehingga mereka dengan mudah menerima dan bergabung di dalamnya. Pertimbangan mereka bergabung dalam tarekat salah satunya adalah untuk mencari ketenangan batin, karena dengan bertarekat, mereka yakin akan memperoleh bimbingan untuk dapat mencapai ketenangan batin itu. Dalam tarekat pula, mereka yakin dapat memperoleh pemahaman keilmuan Islam secara komprehensif. Karena di dalam tarekat, dibahas/dipelajari teori keislaman sekaligus prakteknya.

2. Dengan demikian, maka pada dasarnya jama'ah THN, memang cenderung kepada hakikat murni yang cukup ekstrim. Hal ini nampak pada setiap point jawaban dan pandangan mereka yang selalu dikaitkan dengan hakikatnya, seperti bersyahadat dengan hati, berqurban yang terpenting adalah penyerahannya yang ikhlas, puasa untuk menguatkan latifah qalbi, shalat diperjalanan dapat dilakukan dengan berdzikir, haji sebagai safar menuju Allah, dan lain sebagainya. Namun, setelah ditelaah lebih jauh (melalui wawancara dan observasi serta partisipasi langsung), dapat disimpulkan bahwa kondisi ini disebabkan oleh kurangnya pembinaan jama'at terhadap hal-hal yang menyangkut syari'at. 


\section{E. Daftar Pustaka}

Az-Zain, Samih Athif. Syari'at Islam: Dalam Perbindangan Ekonomi, Politik, dan Sosial sebagai Studi Perbandingan, Terjemahan Drs. Muzakir As dari judul Asli: Al-Islam Khuthuthun 'Aridhah: al-lqtishadal-Hukm al-litima' (Beirut: Darul Kitabil Lubnaniy, Cet. IV, 1981), (Bandung: Husaini, 1988).

Bachrun Rif'i dan Mud'is, Hasan. Filsafat Tasawuf, Pustaka Setia, Bandung, 2010.

Gitosaroso, Muh. Tarekat Haq Naqsyabandiyah di Kalimantan Barat: Studi Kasus di Kecamatan Pontianak Timur (Jurnal Dakwah Al-Hikmah, Vol.7. No.1, Tahun 2013).

Hawwa, Sa'id dan Ridho, Abu. Membina Angkatan Mujahid: Studi Analitis atas Konsep Dakwah Hasan AlBanna dalam Risalah Ta'alim (Jakarta: Era Intermedia, 1999).

Mustofa, A. Akhlak Tasawuf (Bandung: Pustaka Setia, 2014).

Nasution, Ahmad Bangun dan Siregar, Rayani Hanum. Akhlak Tasawuf,
Raja Grafindo Persada, Jakarta, 2015.

Ramli, Rushdi. Khazanah Cinta Ilahi (Selangor: Karya Bestari, 2010),

Redaksi Pontianak Post, "Satukan Hati, Raih Kebahagiaan Dunia dan Akhirat", Pontianak Post 28 Desember 2009.

Shihab, M. Quraish. Tafsir al-Mishbah: Pesan dan Kesan Keserasian alQur'an (Jakarta: Lentera Hati, 2002).

Solihin, M. dan Anwar, Rosihon. IImu Tasawuf (Bandung: Pustaka Setia, 2011).

Tafsir, Ahmad. "Rukun Islam Sebagai Maqamat Menuju Tuhan", dalam: http://www.rasailmedia.com/index .php/en/13-artikel/22-rukun-islamsebagai-maqamat-menuju-tuhan, diakses pada tanggal 23 September 2016.

Toriquddin, Sekularitas Tasawuf (Malang: UIN-Malang Press, 2008).

Zuhdi, Masjfuk. Pengantar Hukum Syariah (Jakarta: Haji Masagung, 1990). 